\title{
Protective Effect of L-Hexaguluroic Acid Hexasodium Salt on UVA-Induced Photo-Aging in HaCaT Cells
}

\author{
Qiong Li ${ }^{1,2}$, Donghui Bai ${ }^{1,2}$, Ling Qin ${ }^{1}$, Meng Shao ${ }^{1,2}$, Xi Liu ${ }^{1,2}$, Shuai Zhang ${ }^{1,2}$, \\ Chengxiu Yan ${ }^{1,2}$, Guangli Yu $1,2,3, * \mathbb{D}$ and Jiejie Hao ${ }^{1,2,3, *}$ \\ 1 Key Laboratory of Marine Drugs, Ministry of Education, School of Medicine and Pharmacy, \\ Ocean University of China, Qingdao 266003, China; liqiong3360@163.com (Q.L.); \\ 17806250053@163.com (D.B.); QinlingOUC@163.com (L.Q.); betty0301@126.com (M.S.); \\ liuxicsu1992@163.com (X.L.); m13695312569@163.com (S.Z.); Dyan2221@163.com (C.Y.) \\ 2 Shandong Provincial Key Laboratory of Glycoscience and Glycotechnology, \\ School of Medicine and Pharmacy, Ocean University of China, Qingdao 266003, China \\ 3 Laboratory for Marine Drugs and Bioproducts, Pilot National Laboratory for Marine Science and \\ Technology (Qingdao), Qingdao 266237, China \\ * Correspondence: glyu@ouc.edu.cn (G.Y.); 2009haojie@ouc.edu.cn (J.H.); Tel./Fax: +86-532-8203-1913 (J.H.)
}

Received: 7 January 2020; Accepted: 9 February 2020; Published: 11 February 2020

\begin{abstract}
This study aimed to show the $\alpha$-L-Hexaguluroic acid hexasodium salt (G6) protective effect against UVA-induced photoaging of human keratinocyte cells. We found that G6 localized to the mitochondria and improved mitochondrial functions. G6 increased respiratory chain complex activities, which led to increased cellular ATP content and NAD ${ }^{+} / \mathrm{NADH}$ ratio. Thus, G6 alleviated the oxidative stress state in UVA-irradiated cells. Moreover, G6 can regulate the SIRT1/pGC- $1 \alpha$ pathway, which enhanced the cells' viability and mitochondria energy metabolism. Notably, the anti-photoaging potential of G6 was directly associated with the increased level of MMP and SIRT1, which was followed by the upregulation of $p G C-1 \alpha, D-L O O P$, and Mt-TFA, and with the transcriptional activation of NRF1/NRF2. Taking all of the results together, we conclude that G6 could protect HaCaT cells from UVA-induced photo-aging via the regulation of mitochondria energy metabolism and its downstream signaling pathways.
\end{abstract}

Keywords: $\alpha$-L-hexaguluroic acid hexasodium salt; HaCaT cells; UVA-induced photo-aging; mitochondrial dysfunction

\section{Introduction}

It is well known that repeated exposure to ultraviolet (UV) radiation contributes to photo-aging of the skin. The hypertrophy of the epidermis and occasional hyperkeratosis of the stratum corneum are involved in the histological features of photo-aging [1,2]. Indeed, an increase in the thickness of the basement membrane and an irregular distribution of melanocytes along the basement membrane were also observed [3,4]. Depending on their wavelengths, ultraviolet rays enter the skin to different degrees and interact with skin cells [3-5]. Among the ultraviolet rays, UVA (320-400 nm) can penetrate the epidermis and reach the dermis layer, which mainly causes skin photo-aging [6-8]. UVA radiation acts on melanocytes and other skin cells, such as keratinocytes, to cause DNA damage through oxidative stress and the production of reactive oxygen species (ROS), which activate signaling pathways associated with cell and tissue growth, differentiation, senescence, and photo-aging [9-11]. Moreover, ROS produced in UVA-irradiated human skin cells are primarily responsible for photo-aging [1,12].

The ROS produced in the mitochondria account for almost $90 \%$ of the total ROS production in cells $[12,13]$. Even though the process of oxidative phosphorylation is effective during normal 
breathing, a small fraction of electrons may "leak" from the electron transport chain (ETC), especially from complexes I and III reduce oxygen to form ROS [13]. Other mitochondrial proteins, such as alpha-glycerophosphate dehydrogenase, alpha-ketoglutarate, and pyruvate dehydrogenase, have been shown to play a role in ROS production [14]. The mitochondria are also the only organelle in animal cells that have their own mtDNA, which is located physically close to the mitochondrial respiratory chain (MRC). Moreover, those point mutations and deletions in mtDNA were reported to accumulate more and more in various tissues during aging [15], which might consequently lead to the declined MRC capacity in various tissues, such as the skeletal muscle and liver [16,17]. In addition, the fact that the mitochondrial ETC is the major ROS production site results in mitochondria being the primary target for oxidative damage. Related studies have shown that with age, mitochondria become larger, decrease in the number, accumulate vacuoles, sputum abnormalities, and experience mitochondrial rupture $[18,19]$.

More importantly, oxidative damage of protein and mtDNA, accompanied by mtDNA mutations, could result in a decrease in mitochondrial respiratory chain enzyme activities, mitochondrial membrane potential, and ATP production [19]. It has been demonstrated that creatine enhances DNA repair caused by UV-induced stress exposure in skin models [20]. Notably, in human clinical settings, formulations containing creatine, acetyl L-carnitine, and NADH can reduce the appearance of aging [21]. The researchers believe that the repair is due to the increased availability of ATP provided by creatine. Under the pressure of ultraviolet light, cells can use this additional ATP to synthesize the required repair enzymes [20,21].

Meanwhile, ultraviolet irradiation can also induce the expression of the ROS production, leading to skin inflammation and downregulation of SIRT1 [22]. It has been reported that an enhancement in sirtuin genes and pGC- $1 \alpha$ can increase the activities of complexes I and IV, which reduces oxidative stress [23]. SIRT1 is a nuclear protein belonging to the family of nicotinamide adenine dinucleotide dependent enzymes. Moreover, SIRT1 plays a key role in regulating cell growth, proliferation, and senescence. Therefore, SIRT1 inhibition is generally thought to be a hallmark of aging [24,25], and SIRT1 is involved in UV-induced DNA damage repair, cell metabolism, and photo-aging [26]. A growing body of evidence supports the hypothesis that photo-aging is regulated by a sustained crosstalk between ROS and SIRT1 $[27,28]$. Moreover, some reports demonstrated that SIRT1 becomes active to protect cells from oxidative stress and reduce ROS production [28-31].

Marine alginate is a natural anionic polysaccharide extracted from brown algae such as Laminaria japonica. It consists of $\alpha$-L-guluronic acid $(\mathrm{G})$ and $\beta$-D-mannuronic acid $(\mathrm{M})$ that occur in homopolymeric M blocks (M-blocks), heteropolymeric random MG blocks (MG-blocks), and homopolymeric G blocks (M-blocks). It has been widely studied and applied in chemical industry, medicinal technology, and food engineering [31]. Moreover, alginate oligosaccharides produced by a variety of degradation methods exhibit excellent biomedical activities including anti-inflammatory activity, antioxidant activity, and neuron protection effects [32-34]. However, the protective effect of $\alpha$-L-Hexaguluroic acid hexasodium salt (G6, Figure 1) is rarely reported. The present study evaluated the protective effect of G6 on photo-aging of HaCaT cells induced by UVA and its mechanism of action. According to our research, G6 is a purely natural ingredient with no toxic side effects. It has high potential to be developed into anti-photo-aging drugs or functional foods with good development and application prospects.

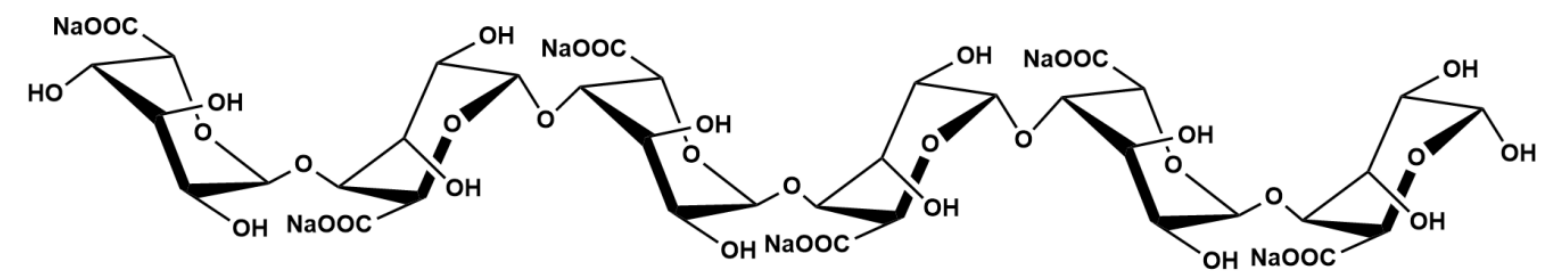

Figure 1. Chemical structure of $\alpha$-L-Hexaguluroic acid hexasodium salt (G6). 


\section{Results}

\subsection{G6 Inhibits UVA-Irradiated Cytotoxicity in HaCaT Cells}

The effects of UVA and G6 on HaCaT cells viability were detected by MTT assays. Additionally, the control group was normalized to be considered as $100 \%$. The $10 \mu \mathrm{M}$ (G1-G8)-pretreated were significantly protected HaCaT cells from the irradiation of UVA (Figure 2a). In addition, the cells' viability after G6 treatment was not significantly different from those in the control group, indicating that G6 up to $600 \mu \mathrm{M}$ had no significant cytotoxicity (Figure 2b). Moreover, G6 (2, 10, 50, 200, and $400 \mu \mathrm{M}$ )-pretreated were significantly protected HaCaT cells from the irradiation of UVA (Figure 2c).

(a)

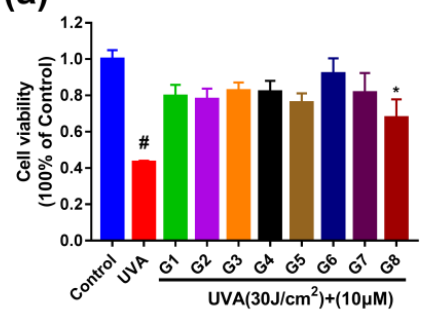

(b)

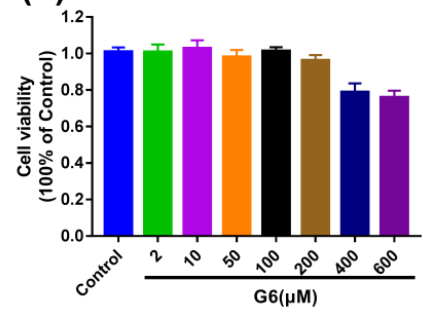

(c)

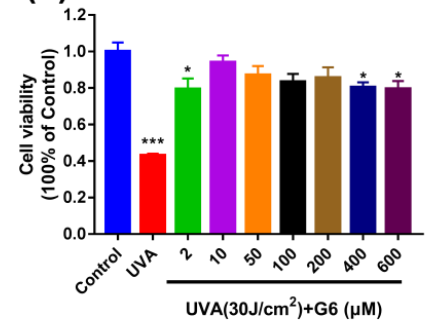

Figure 2. Effects of G6 on cytotoxicity of HaCaT cells determined using MTT assays. (a) The HaCaT cells were pretreated with $10 \mu \mathrm{M}$ G1-G8 for $48 \mathrm{~h}$, and then irradiated with UVA ( $30 \mathrm{~J} / \mathrm{cm}^{2}$ ). (b) HaCaT cells were treated with $0,2,10,50,100,200,400$, or $600 \mu \mathrm{M} \mathrm{G6}$ for $48 \mathrm{~h}$. (c) The cells were pretreated with 0-600 $\mu \mathrm{M}$ G6 for $48 \mathrm{~h}$, and then irradiated with UVA $\left(30 \mathrm{~J} / \mathrm{cm}^{2}\right)$. Values are the mean of nine replicates \pm S.E.M $(n=9)$. Significant difference compared to the control group, ${ }^{*} p<0.05,{ }^{* * *} p<0.001$ and $\# p<0.0001$.

\subsection{Effect of $G 6$ on Mitochondrial Membrane Potential (MMP)}

We performed a JC-1 assay to determine changes in mitochondrial membrane potential induced by different doses of G6. Figure 3 shows that $30 \mathrm{~J} / \mathrm{cm}^{2}$ of UVA significantly induced a significant decrease in MMP in HaCaT cells. As shown in Figure 3, pretreatment of HaCaT cells with different concentrations of G6 significantly reversed the decrease in $\Delta \Psi \mathrm{m}$ in HaCaT cells induced by UVA as determined using JC-1 assay. At a dose of 2-600 $\mu \mathrm{M}$ of G6 tends to increase the mitochondrial membrane potential. Moreover, the concentration of 2,10 , and $200 \mu \mathrm{M}$ is preferred. For all subsequent experiments, the G6 $(10 \mu \mathrm{M})$ was selected.

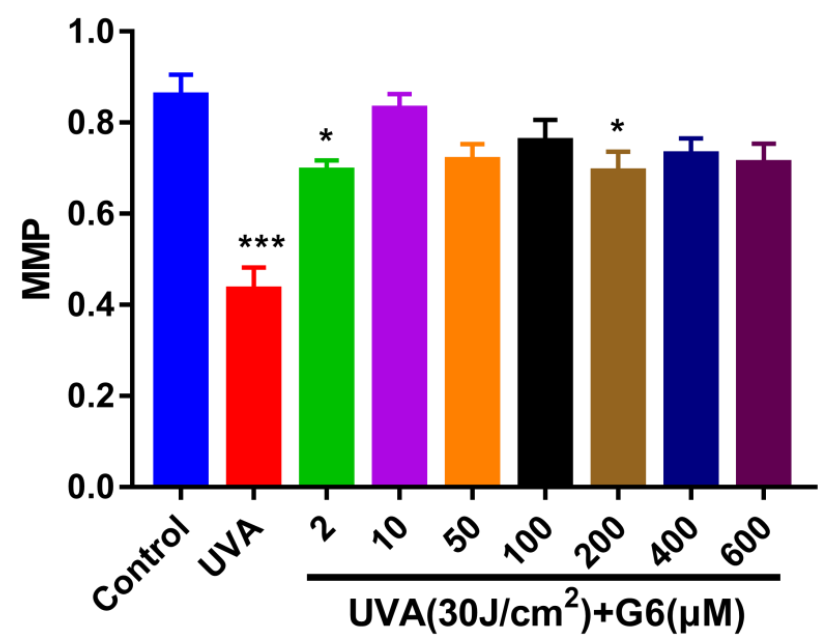

Figure 3. HaCaT Cells were incubated with specific concentrations of G6 for $48 \mathrm{~h}$ and then irradiated with UVA $\left(30 \mathrm{~J} / \mathrm{cm}^{2}\right)$. Significant difference from control group: ${ }^{*} p<0.05$ and ${ }^{* * *} p<0.001$, bars and error bars are expressed as mean \pm S.E.M $(n=9)$. 


\subsection{G6 Co-Localize with Mitochondria}

To verify whether FITC was tagged on G6, the reaction product and FITC (as a negative control) were separated on silica gel plate with $\mathrm{ddH}_{2} \mathrm{O}$ :chloroform:methanol (0.1:3:1) and were then observed at $365 \mathrm{~nm}$. As shown in Figure 4a, the fluorescence of the FITC-only group was in the upper part of the plate, and the FITC-G6 line was only in the bottom of the silica gel plate. Our results suggested that G6 was successfully labeled with FITC. Additionally, we detected the compounds with the aniline:diphenylamine:phosphoric acid reagent. Then, this compound was used to detect the localization of G6 in HaCaT cells.

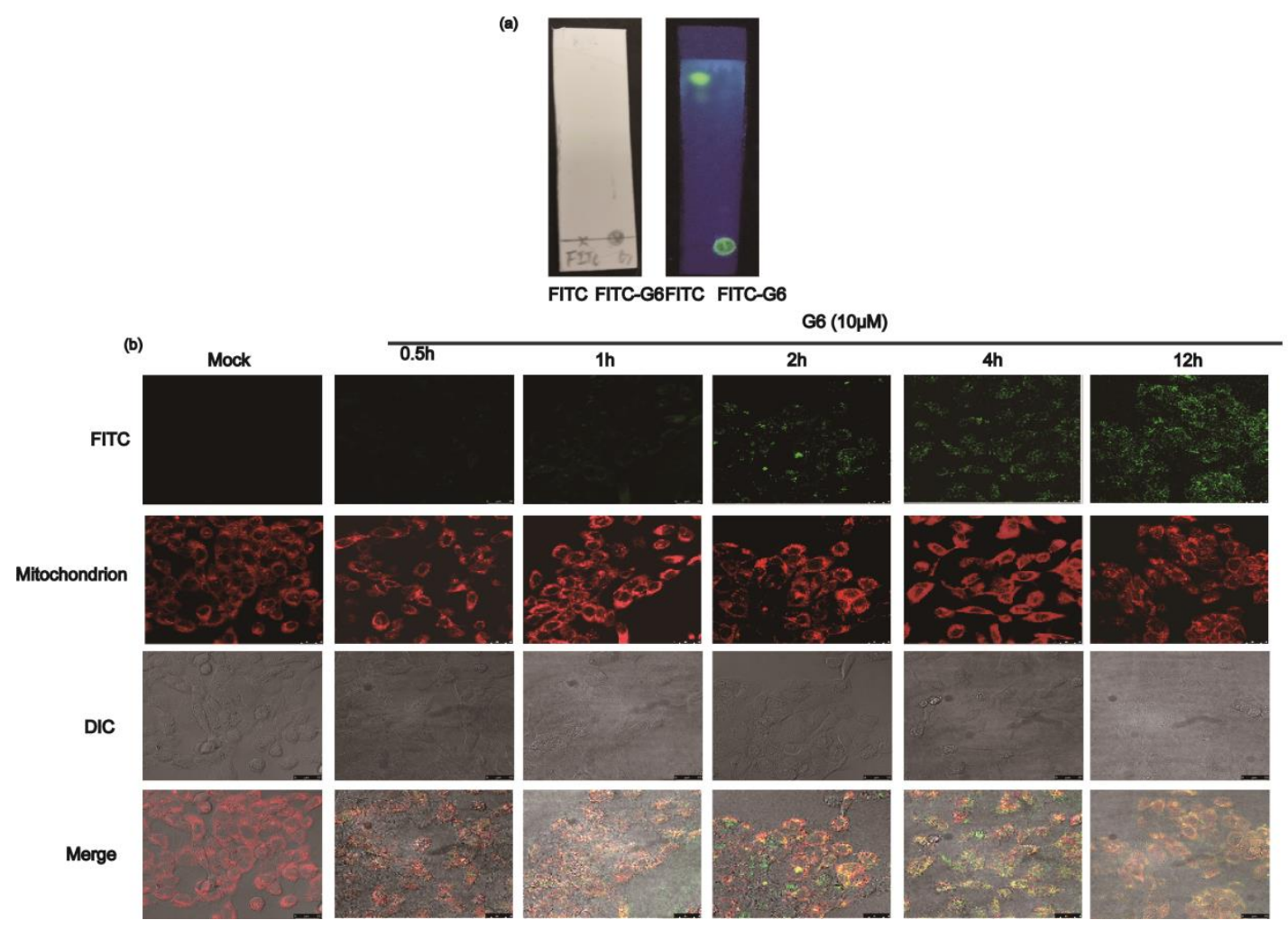

Figure 4. G6 localizes to the mitochondria. (a) Thin-layer chromatography results of FITC labeled G6; (b) laser-scanning confocal microscopy images of HaCaT cells incubated with MitoTracker Red CMXRos (100×) and FITC-G6. Red fluorescence from MitoTracker Red CMXRos and green fluorescence from FITC-labeled G6, and orange-yellow fluorescence from these two merged sources of fluorescence.

The co-localization studies were performed to identify the intracellular localization of G6 in HaCaT cells using confocal fluorescence microscopy. Some researchers have shown that the dysfunction of mitochondria participates in processes of UVA-induced photo-aging [32-36], which motivated us to investigate the presence of G6 in the mitochondria using MitoTracker Red CMXRos. As shown in Figure 4b, incubation with MitoTracker Red CMXRos (red) and FITC-labeled G6 (green) resulted in some punctuated staining patterns of orange-yellow fluorescence when the respective channels were merged. Our results suggest that G6 and mitochondria were co-localized. Therefore, G6 was primarily localized in mitochondria. Moreover, we found that G6 has a direct interaction with mitochondria, which directly affect mitochondrial functions.

\subsection{Effect of $G 6$ on ROS Production, ATP Content, and NAD $/ N A D H$ Ratio Change}

As shown in Figures 2 and 3, the optimal concentrations of G6 for protecting HaCaT cells from UVA irradiation were 2, 10, and $200 \mu \mathrm{M}$. Figure 5a shows that $10 \mu \mathrm{M}$ of G6 markedly reduced ROS levels. Thus, to reach sufficiently maximal protection of G6, we used $10 \mu \mathrm{M}$ treatment for $48 \mathrm{~h}$ in the following tests. Meanwhile, Figure $5 \mathrm{~b}$ indicated that UVA $\left(30 \mathrm{~J} / \mathrm{cm}^{2}\right)$ significantly reduced ATP levels. 
As expected, pretreatment with $10 \mu \mathrm{M}$ G6 significantly increased ATP levels in UVA-induced HaCaT cells. These results indicated that the pretreatment of $10 \mu \mathrm{M}$ G6 was the most effective in protecting UVA-irradiated $\mathrm{HaCaT}$ cells. Additionally, we continued to measure the changes of $\mathrm{NAD}^{+} / \mathrm{NADH}$ ratio in $\mathrm{HaCaT}$ cells. Figure $5 \mathrm{c}$ shows that the intracellular $\mathrm{NAD}^{+} / \mathrm{NADH}$ ratio was markedly decreased, after $30\left(\mathrm{~J} / \mathrm{cm}^{2}\right)$ UVA irradiation of HaCaT cells. Whereas, the addition of $10 \mu \mathrm{M} \mathrm{G} 6$ significantly increased the intracellular $\mathrm{NAD}^{+} / \mathrm{NADH}$ ratio. Furthermore, there was a significant difference in the $\mathrm{NAD}^{+} / \mathrm{NADH}$ ratio between the HaCaT cell after $10 \mu \mathrm{M}$ G6 was added to the normal cells and the control groups. Results of ROS production assay are shown in Figure 5 a. Treatment with UVA $\left(30 \mathrm{~J} / \mathrm{cm}^{2}\right)$ resulted in a significant increase in ROS production in HaCaT cells. Moreover, G6 markedly decreased cellular ROS production of $\mathrm{HaCaT}$ cells.

(a)

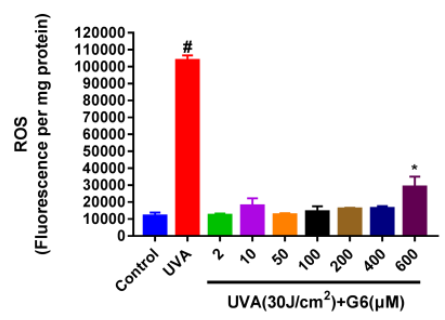

(b)

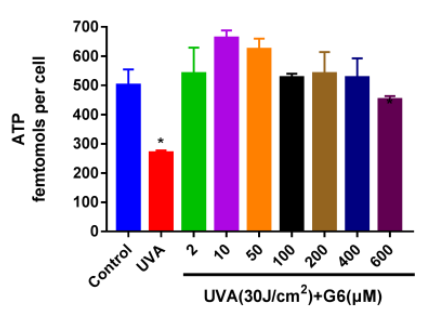

(c)

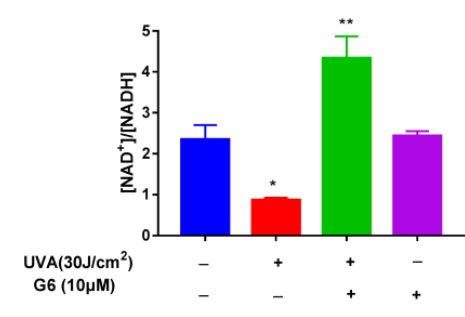

Figure 5. Effect of $\mathrm{G} 6$ on ROS production, ATP content, and $\mathrm{NAD}^{+} / \mathrm{NADH}$ ratio change. (a) The reactive oxygen species (ROS) production assay using $2 \mu \mathrm{M}$ MCFH2-DA probe; (b) the ATP content; (c) the $\mathrm{NAD}^{+} / \mathrm{NADH}$ ratio change. The values are presented as the means \pm S.E.M from at least nine independent experiments. Significant difference from control group: ${ }^{*} p<0.05,{ }^{* *} p<0.01$ and $\# p<0.0001$.

\subsection{Effect of G6 on Mitochondrial Functions}

To explore whether G6 can affect cellular mitochondrial function, we measured the activity of mitochondrial complex I and complex II. Figure 6 shows that $10 \mu \mathrm{M}$ G6 pretreatment significantly increased the activity of mitochondrial complex I and complex II in $\mathrm{HaCaT}$ cells. These results shown in Figure 6 indicated that G6 can significantly enhance mitochondrial function.

(a)

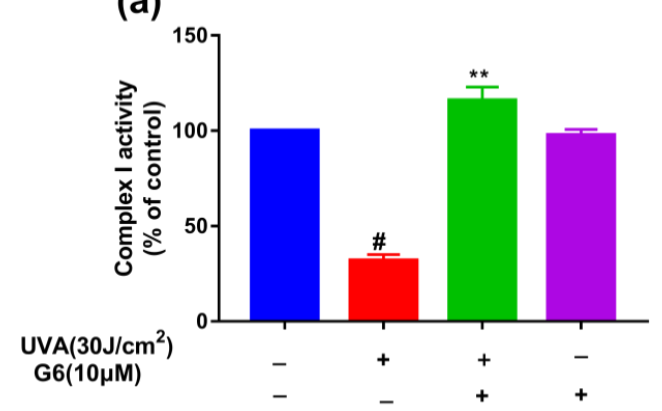

(b)

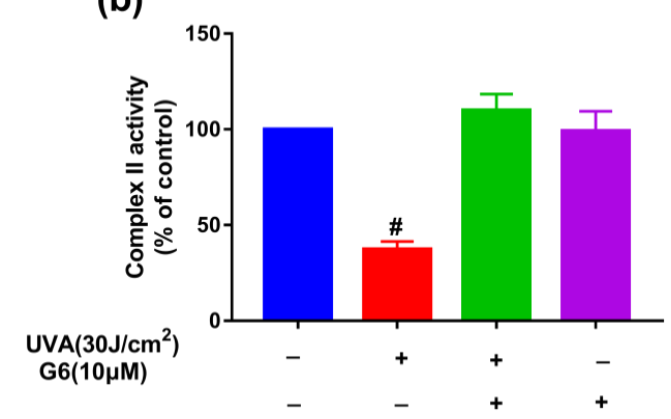

Figure 6. Effect of G6 on mitochondrial functions. (a) Activities of complex I; (b) activities of complexe II. (blue color, the control group; red color, treated with $30 \mathrm{~J} / \mathrm{cm}^{2} \mathrm{UVA}$; green color, treated with $30 \mathrm{~J} / \mathrm{cm}^{2}$ UVA and $10 \mu \mathrm{M}$ G6; black color, treated with $10 \mu \mathrm{M}$ G6.) The values are presented as the means \pm S.E.M from at least three independent experiments. Significant difference from control group: ${ }^{* *} p<0.01$ and $\# p<0.0001$.

\subsection{Molecular Docking Predicted the Possible Interaction between G6 and SIRT1 Protein}

Molecular docking can predict the possible binding sites of G6 within the active cavity of SIRT1 at SIRT1:G6 binding ratios of 1:1 (Figure 7). As shown in Figure 7, residues of Asp-204, Glu-416/208, Lys-203, and Arg-446 formed hydrogen bonds with one molecule of G6. Furthermore, these residues were also observed in the crystal structure of SIRT1/G6 complex with the 1:1 ratio, which interacted 
with G6 by hydrogen bonds. The observed results showed that it is likely that G6 binds within the SIRT1 pocket to produce a stable complex. Previous research supports our findings (Figure 7).

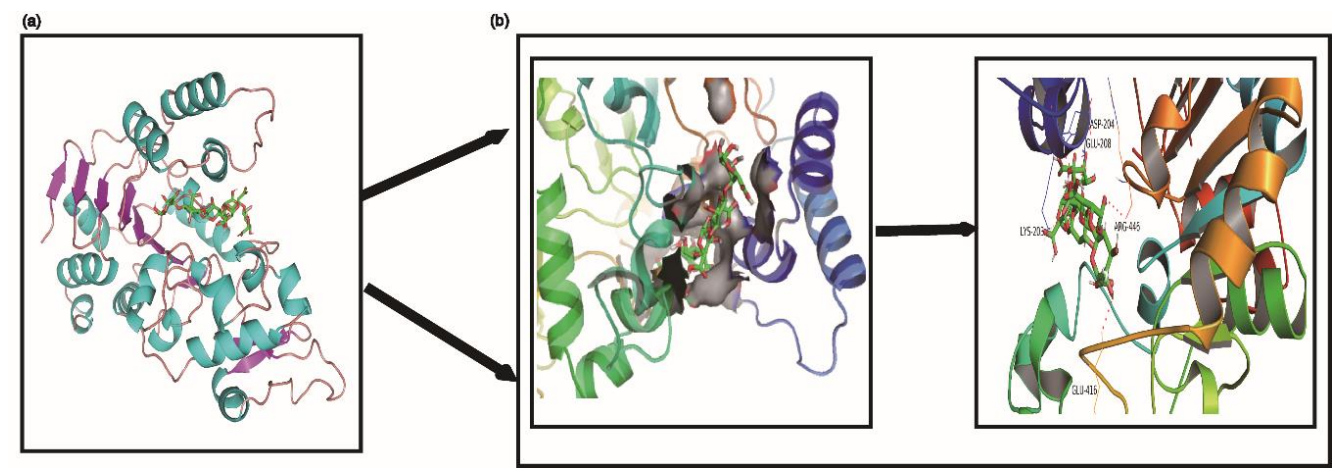

Figure 7. Molecular docking predicted the possible interaction between G6 and SIRT1 protein. (a) The electrostatic surface representation; (b) cartoon representation of the docking model of G6 binding to human SIRT1, using PyMOL1.8.

\subsection{Effect of G6 on Key Protein Expressions of SIRT1 Signaling Pathway}

We performed Western blot analysis to measure the expression of SIRT1 and pGC-1a. As shown in Figure 8, the level of SIRT1 and pGC-1a proteins were significantly downregulated in the UVA group. After treatment with $10 \mu \mathrm{M} \mathrm{G6}$, the content of SIRT1 and pGC-1a protein increased. Additionally, the level of SIRT1 and pGC-1a in HaCaT cells were not significantly different from those in the control group (Figure 8a,b). As shown in Figure 8b,c, the level of pGC-1a protein and MMP sharply decreased, meanwhile the expression of ROS increased using $80 \mathrm{mM}$ NAM in HaCaT cells. Consistent with these data, the levels of SIRT1, pGC-1a protein, and MMP markedly decreased, and the content of ROS significantly increased via co-treatment with $10 \mu \mathrm{M}$ G6 and 80mM NAM in HaCaT cells. Clearly, $10 \mu \mathrm{M}$ G6 reversed the downregulation of SIRT1 and pGC-1a expression levels in UVA-irradiated HaCaT cells, and SIRT1 protein is the key target.

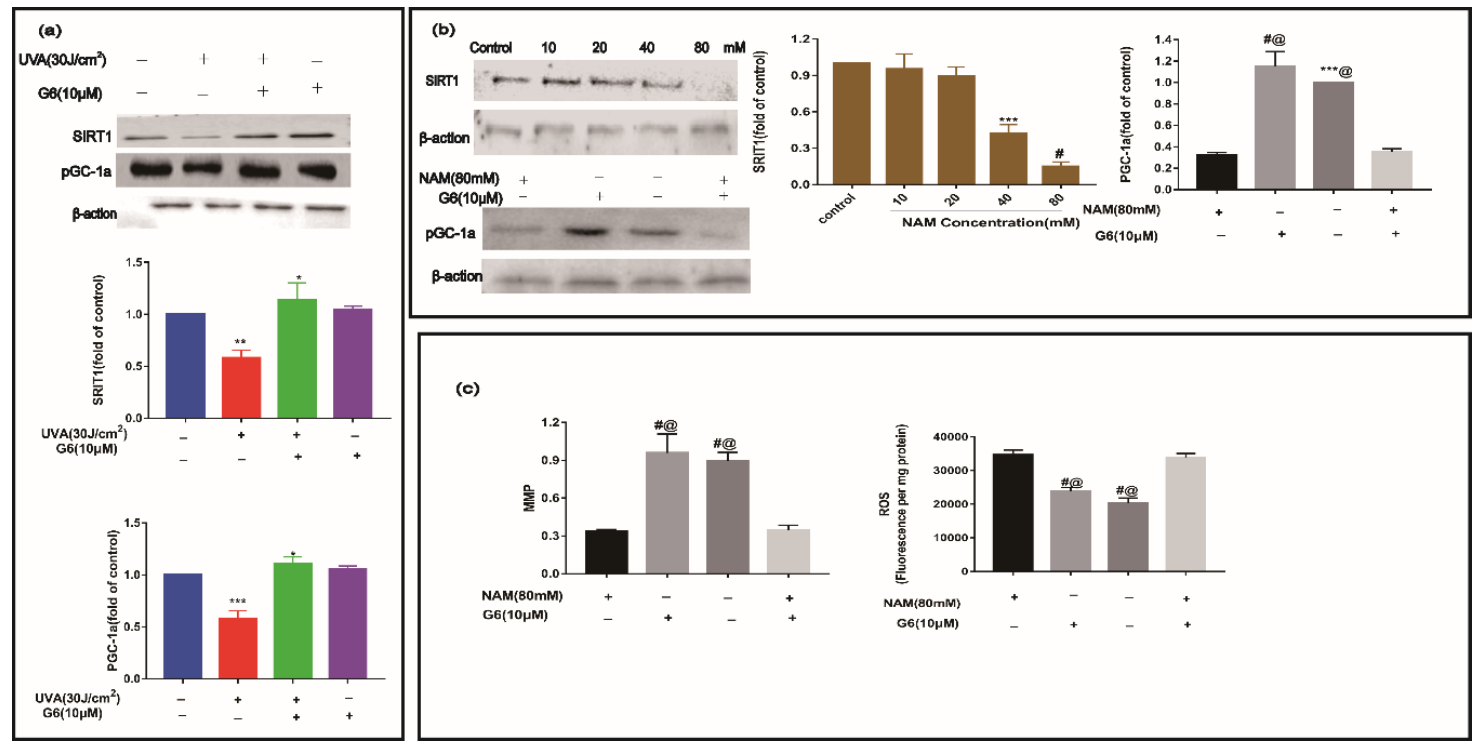

Figure 8. Effect of G6 on SIRT1 and pGC1a protein expression in HaCaT cells. (a) HaCaT cells were treated with or without G6 for $48 \mathrm{~h}$, and were then incubated in the presence or absence of UVA. (b) Furthermore, HaCaT cells were incubated in the presence or absence of $80 \mathrm{mM}$ NAM, and treated with or without G6 for 48 h. (c) The levels of MMP and ROS. Values are the mean \pm S.E.M of results from at least three independent experiments, significant difference compared to the control group, *** $p<0.001$ and \# $p<0.0001 ; * * *$, $p<0.001$ and \#,@ $p<0.0001$, compared with the NAM-treated group, ${ }^{*} p<0.05,{ }^{* *} p<0.01$. 


\subsection{Effects of $G 6$ on the mRNA Expression of SIRT1 Pathways}

It has been confirmed that SIRT1 and pGC-1a promote mitochondrial regeneration and energy metabolism by modulating multiple steps in AMPK/FoXO1 pathways [37]. Additionally, the role of G6 in the SIRT1 signaling pathway was explored using RT-PCR assays. As shown in Figure 9, SIRT1 mRNA content was markedly increased compared to the control group after $24 \mathrm{~h}$ of G6 treatment. Meanwhile, $10 \mu \mathrm{M}$ G6 co-acted with normal cells, and the expression of SIRT1 mRNA was not significantly different from the control group. Additionally, in Figure 9, the mRNA expressions of the target gene downstream of the SIRT1 pathway were consistent with SIRT1.

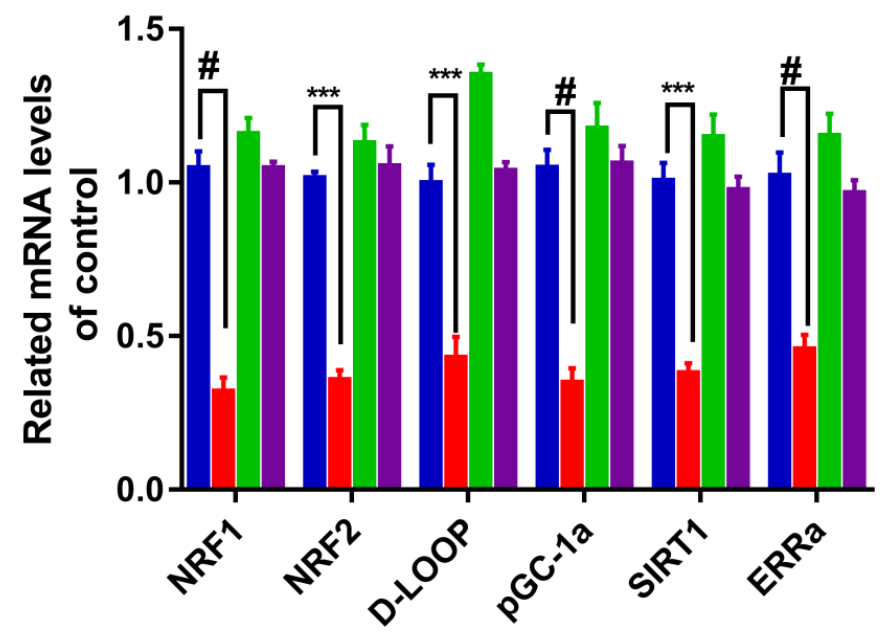

Control UVA $\left(30 \mathrm{~J} / \mathrm{cm}^{2}\right)$ G6 $(10 \mu M)+U V A$

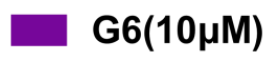

Figure 9. Effect of G6 treatment on mRNA expression of the SIRT1/ pGC-1a pathway in HaCaT cells. HaCaT cells were pretreated with G6 $(10 \mu \mathrm{M})$ in MEM medium for $24 \mathrm{~h}$. Then, the cells were exposed to UVA $\left(30 \mathrm{~J} / \mathrm{cm}^{2}\right)$ irradiation. mRNA levels were analyzed by RT-PCR as described in Section 4.13. Values are means \pm SEM from six independent experiments, significant difference compared to the control group, $\# p<0.0001$ and ${ }^{* * *} p<0.001$.

\section{Discussion}

The skin is the main organ to protect the body from noxious substances, such as toxic chemicals and ultraviolet radiation, which lead to skin photo-aging or skin cancer [38]. The main source of UV exposure in humans is ultraviolet A (UVA) rays, which causes the generation of reactive oxygen species (ROS), such as hydrogen peroxide, superoxide anion, and hydrogen peroxide [39]. In addition, ROS are the critical mediators of many of UV-induced biological effects [40-42]. The ROS produced after UVA irradiation induce direct oxidative damage to skin constituents and may also indirectly cause damage to cellular structural proteins, lipids, and polysaccharides [43]. As UVA-induced cell damage is mainly attributed to the harmful effects of free radicals, molecules that can scavenge radicals are primarily promising as radio-protectors.

In our study, the protective ability of G6 and the underlying biology mechanisms against UVA-induced photo-aging in HaCaT cells were revealed. G6 markedly enhanced the activity of pGC- $1 \alpha$ by upregulating SIRT1. In addition, as both the activity of $p G C-1 \alpha$ and the expression levels of NRF-1, NRF-2, and ERR $\alpha$ increased, and the intracellular ROS content decreased. Meanwhile, the activation of Mt-TFA and D-Loop promoted mitochondrial production and metabolism, and then increased MMP and ATP expression. In this study, we demonstrated that the protective effect of G6 against UVA-induced photo-aging in HaCaT cells is mainly mediated by SIRT1/pGC-1 $\alpha$ activation. The results suggest that G6 is an effective component in food supplements for anti-photo-aging and skin protection. Our results suggest that G6 can be used for the preparation of skincare products, such as dermatological creams or lotions, to develop the regeneration and repair of UVA-irradiated skin. UVA exposure leads to oxidative stress by the overexpression of ROS. As a result of the oxidative 
stress, in spite of the enzymatic and non-enzymatic antioxidant defense systems of the skin that has been damaged, there is oxidative damage of mitochondrial DNA (mtDNA), genomic DNA, proteins, and lipids. Notably, the key target for ROS is mtDNA, as its decline and damage in function lead to vicious cycle-like effects, by further enhancing the ROS content [44].

In this study, we demonstrated that the production of ROS increased, and the viability of HaCaT cells decreased after UVA irradiation, whereas G6 enhanced cell viability and the decrease of ROS generation. Therefore, we revealed that G6 can protect HaCaT cells from UVA-induced oxidative damage. This result was consistent with those of Abbas Mirshafiey et al. (2016), who determined that the small molecule $\mathrm{G} 2013\left(\mathrm{C}_{6} \mathrm{H}_{10} \mathrm{O}_{7}\right)$ decreases the content of ROS in rats [45]. G2013 was recommended as an anti-aging and preventive agent for a number of diseases related to free radicals [46]. In addition, the ROS produced in mitochondria account for almost $90 \%$ of total cellular ROS. The fact that the mitochondrial electron transport chain is the major ROS production site makes mitochondria the key target of oxidative damage. Therefore, the mitochondrial aging theory is associated with the free radical theory $[15,47]$.

The overexpression of ROS results in mtDNA damage and other structures of the cell are also damaged, such as lipids, membranes, and proteins. The mtDNA damage in sites coding for ETC proteins decreases the ATP content, and further increases the ROS content [48-51]. Notably, the inner mitochondrial membrane (mainly at complexes I and II) is the main target of ROS damage [50,52]. As shown in Figures 3-6, our results revealed that UVA irradiation results in a decrease of MMP, ATP content, and complex I/II activities in HaCaT cells. Importantly, the pretreatment with G6 removed the UVA-induced mitochondrial metabolic disorder. Moreover, our present study (Figure 4) showed that G6 and mitochondria colocalize. These findings further suggest that G6 directly interacts with the mitochondria. Furthermore, our observations also showed that G6 is primarily localized in the mitochondria and directly affects the mitochondrial functions (Figure 6). Mitochondrial retrograde signaling starts with several main signals (such as ROS, ADP/ATP, and NAD ${ }^{+} / \mathrm{NADH}$ ratios), and ROS can lead to aging [53]. As shown in Figure 5b,c, exposure to UVA radiation can reduce ATP generation and $\mathrm{NAD}^{+} / \mathrm{NADH}$ ratio. The pretreatment with G6 significantly reversed the UVA-induced decrease of ATP content and $\mathrm{NAD}^{+} / \mathrm{NADH}$ ratio, to the extent that the levels of these molecules were close to those of non-irradiated cells.

In addition, these retrograde messengers activate cytosolic transducers by an oxidative modification that interact with small molecules, including $\mathrm{Ca}^{2+}, \mathrm{NAD}^{+}$, and $\mathrm{AMP}$, which modulate the activities of certain transcription factors. These include pGC-1a, SIRT1, mTOR, and CREB, which affect the mitochondrial and cellular function, namely the energy supply, and then change the progress of cellular senescence and proliferation [54-56]. SIRT1 is a member of the family of sirtuins that catalyze the deacetylation of various substrates by utilizing nicotinamide $\left(\mathrm{NAD}^{+}\right)$as a substrate [57]. Furthermore, the $\mathrm{NAD}^{+} / \mathrm{NADH}$ ratio is much higher than control in the case of UVA+G6. Furthermore, it regulates the activity of several substrates, including peroxisome proliferator-activated pGC- $1 \alpha$ and p53 in some signaling pathways, such as the Rap1/Ras, PI3K-Akt, MAPK, and longevity regulating pathway $[22,58,59]$. On the one hand, it has been reported that SIRT1 plays an important role in regulating cellular homeostasis via influencing neuron survival, insulin sensitivity, glucose metabolism, and mitochondrial biogenesis $[60,61]$. On the other hand, it can increase pGC- $1 \alpha$ activity and inhibit ROS production, which improves mitochondrial dysfunction [62]. Those previous works support our findings (Figure 8). In addition, our report demonstrated that G6 regulates mitochondrial biogenesis and metabolism by activating the NADH/SIRT1/pGC- $1 \alpha$ signaling pathway in HaCaT cells (Figures 8 and 9). It has been reported that adding nicotinamide riboside or nicotinamide mononucleotide in XPA cells can promote the NAD ${ }^{+}$-SIRT1-pGC- $1 \alpha$ via decreasing the PARP effect and then reversing the mitochondrial dysfunction [36]. NRF2 is a key transcription factor regulating the redox balance in skin aging because it is important to activate the antioxidant system and prevent further decrease of ROS in all types of skin cells [63]. Several in vitro studies have confirmed that the upregulation of the NRF2-related pathway can protect keratinocytes and melanocytes from UVB-induced photo-aging $[1,64]$. Keratinocytes with 
the NRF1 gene silenced are sensitive to killing after UVB-irradiation $[65,66]$. In addition, pGC1 $\alpha$ activation is controlled by deacetylation of lysine residues via the deacetylase SIRT1 [67], which promotes mitochondrial biogenesis [68] and controls the generation of mitochondrial transcription factor A (Mt-TFA) [69]. Here, we demonstrated that G6 protects HaCaT cells from UVA-induced photo-aging mainly through activating SIRT1 and its downstream target genes (e.g., D-LOOP, NRF1/NRF2, $p G C-1 \alpha$, $E R R a$, and Mt-TFA), as shown in Figure 9.

In summary, our study revealed the molecular mechanism by which G6 protects $\mathrm{HaCaT}$ cells from UVA-induced photo-aging: the activation of the antioxidant system by the upregulation of SIRT1/pGC- $1 \alpha$ is critical for the protection of skin cells from UVA-induced photo-aging. In vitro experiment results showed G6 had activated the antioxidant system, which indicated the high potential of G6 as a candidate supplement for skin protection or the preparation of skincare products.

\section{Materials and Methods}

\subsection{Materials and Reagents}

G6 (Figure 1), with chemical and physical properties in Table 1, was purchased from Lantai Pharmaceutical Company (Qingdao, China). Fetal bovine serum (FBS), streptomycin, penicillin G, and MEM medium were purchased from Gibco (Grand Island, NY, USA). Anti-SIRT1 (\#2496T), anti- $\beta$-actin (\#4970s), and anti-pGC-1a (\#GR3210687-3). All other reagents were purchased from Sigma-Aldrich Chemical Co. (St. Louis, MO, USA).

Table 1. The chemical and physical properties of G6.

\begin{tabular}{cccccc}
\hline Formula & Mw & Source & Purity & Storage & Properties \\
\hline $\mathrm{C}_{36} \mathrm{H}_{44} \mathrm{O}_{37} \mathrm{Na}_{6}$ & $1206.65 \mathrm{Da}$ & $\begin{array}{c}\text { Marine } \\
\text { brown algae }\end{array}$ & $\geq 96 \%$ & $0 \sim-20{ }^{\circ} \mathrm{C}$ & $\begin{array}{c}\text { Off-white to light yellow powdery } \\
\text { or flocculent lyophilisate; odorless, } \\
\text { non-irritating odor; hygroscopic }\end{array}$ \\
\hline
\end{tabular}

\subsection{Cell Culture and Treatments}

The human HaCaT cell line was obtained from the American Type Culture Collection (ATCC, Manassas, VA, USA) and cultured in MEM medium supplemented with 10\% heat inactivated FBS, $2 \mathrm{mM}$ glutamine, and 1\% penicillin/streptomycin. HaCaT cells were used within seven generations.

Firstly, Human keratinocyte HaCaT cells $\left(2 \times 10^{4}\right.$ cells/mL) were grown in 96-well plates for $12 \mathrm{~h}$. Then, those cells were incubated in serum MEM with or without various concentrations of G6 in a humidified atmosphere of $5 \% \mathrm{CO}_{2}$ at $37^{\circ} \mathrm{C}$ for $48 \mathrm{~h}$. The medium was discarded, serum-containing MEM was added and exposed in different doses of UVA irradiation. After the light source was slaked, it was incubated in a cell incubator.

\subsection{MTT Assay}

After the cells were treated for $24 \mathrm{~h}$, the effect of G6 on cell viability was monitored by the MTT assay. MTT solution ( $5 \mathrm{mg} / \mathrm{mL}$ in PBS buffer) was added and incubated for $4 \mathrm{~h}$. Then, the medium was removed and replaced with DMSO to dissolve the potassium salt and the absorbance was measured at $570 \mathrm{~nm}[70,71]$.

\subsection{Measurement of Mitochondrial Membrane Potential (MMP, $\triangle \Psi m$ )}

Determination of MMP was carried out using the proportion dye JC-1 $\left(5,5^{\prime}, 6,6^{\prime}\right.$-tetrachloro$1,1^{\prime}, 3,3^{\prime}$-tetraethyl-benzimidazolyl-carbocyanine iodide) [72]. After the cells were treated for $24 \mathrm{~h}$, the $\mathrm{HaCaT}$ cells were incubated with $10 \mu \mathrm{g} / \mathrm{mL}$ of JC- 1 for $45 \mathrm{~min}$ at $37^{\circ} \mathrm{C}$, and then analyzed by a dual-wavelength/double-beam recording spectrophotometer (Ex490/Em530 and Ex525/Em590). MMP was calculated as follows: $\Delta \Psi \mathrm{m}=\mathrm{A} 525-590 / \mathrm{A} 490-530$. 


\subsection{Measurement of Reactive Oxygen Species (ROS) Generation}

The intracellular accumulation of ROS following UVA radiation was detected by fluorescence microscopy using DCFH2-DA. The HaCaT cells $\left(1.5 \times 10^{5}\right.$ cells/well) were cultured in a 12-well plate in MEM supplemented with 10\% FBS. Then, the culture medium was renewed when the cells reached $85 \%$ confluence. After G6 treatment $(2-600 \mu \mathrm{M})$ for $24 \mathrm{~h}$ and UVA irradiation $\left(30 \mathrm{~J} / \mathrm{cm}^{2}\right)$, cells were incubated with $10 \mu \mathrm{M}$ DCFH-DA in the culture medium at $37^{\circ} \mathrm{C}$ for $35 \mathrm{~min}$. Then, washed twice with PBS buffer. Finally, the fluorescence was measured at a Nikon TE2000 microscope at Ex535/Em610 (Flex Station 384, Molecular Devices, NY, USA) [73,74].

\subsection{Determination of ATP Content}

HaCaT Cells were cultured in six-well plates. After various treatments, cells were cracked by $0.5 \%$ Triton X-100 in $100 \mathrm{mM}$ glycine buffer, $\mathrm{pH}$ 7.4. Intracellular ATP levels were assayed with an ATP bio-luminescence assay kit (Sigma, NY, USA) based on the luciferase-catalyzed oxidation of D-luciferin [75].

\section{7. $N A D^{+} / N A D H$ Ratio Change}

HaCaT cells were seeded in six-well plates at a density of $2 \times 10^{5}$ cells per well. After various treatments, $\mathrm{NAD}^{+} / \mathrm{NADH}$ ratio changes were then determined according to the manufacturer's standard protocol provided with the employed $\mathrm{NAD}^{+} / \mathrm{NADH}$ assay kit (Abcam, Cambridge, UK).

\subsection{Activity of Mitochondrial Complexes I and II}

$\mathrm{HaCaT}$ cells were cultured in $100 \mathrm{~mm}$ plates and washed in PBS. After various treatments, cells were fragmented by ultrasonication, and the crude homogenates were used to test complexes I and II activities. NADH-CoQ oxidoreductase (complex I) activity was assayed according to the Kumar's method [76]. Additionally, succinate-CoQ oxidoreductase (complex II) was assayed by Humphries's method [77].

\subsection{Western Blot Analysis}

Briefly, HaCaT cells were seeded in six-well plates at a density of $1 \times 10^{6}$ cells per well. After various treatments $\mathrm{HaCaT}$ cells were rinsed with PBS and lysed in ice-cold RIPA buffer containing phosphatase inhibitors and protease inhibitor for $45 \mathrm{~min}$. Thirty micrograms of protein were separated on $12 \%$ SDS-PAGE and transferred to a PVDF membrane (Millipore, Bedford, MA, USA) for Western blotting. Western blot analyses with antibodies against SIRT1, pGC1 $\alpha$, and $\beta$-actin were performed as described previously. The blots were captured using enhanced chemiluminescence (Thermo Fisher Scientific, Waltham, MA, USA). Additionally, densitometry analysis was conducted by an Image J software (National Institutes of Health, Bethesda, MD, USA).

\subsection{Real-Time RT-PCR Assay}

HaCaT cells $\left(1 \times 10^{6}\right.$ cells/well $)$ were treated with G6 $(10 \mu \mathrm{M})$. After incubation for $24 \mathrm{~h}$ the solution was discarded, and then irradiated with UVA $\left(30 \mathrm{~J} / \mathrm{cm}^{2}\right)$. After that, HaCaT cells were harvested for the preparation of total RNA by FavorPrep Tissue Total RNA Extraction Mini Kit (Favorgen biotech Corp., Taipei, Taiwan), and $10 \mu \mathrm{L}$ of RNA was reverse transcribed into cDNA using ReverTra Ace qPCR RT Master Mix with gDNA (Toyobo, Japan). Finally, target cDNA levels were quantified by RT-PCR using an ABRE PRISM 7500 Sequence Detection System (Applied Biosystems, San Diego, CA, USA) using SYBR green (Toyobo, Japan). The qPCR assay using the following primers: SIRT1 mRNA, 5' -TCAGTGTCATGGTTCCTTTGC-3' and 5'-AATCTGCTCCTTTGCCACTCT-3'; NRF-1 mRNA, $5^{\prime}$-AGCACGGAGTGACCCAAAC- $3^{\prime}$ and $5^{\prime}$-AGGATGTCCGAGTCATCATAAGA-3'; -LOOP mRNA, $5^{\prime}$-TATGGAGTGACATAGAGTGTGCT- $3^{\prime}$ and $5^{\prime}$-GTCGCTACACCACTTCAATCC- $3^{\prime}$; NRF-2 mRNA, 5'-CAGCGACCTTCGCAAACAAC-3' and 5'-CATGATGAGCTGTGGACCGT-3'; $p G C-1 a$ 
mRNA $5^{\prime}$-TTGCTAAACGACTCCGAGAACA-3' and 5' ${ }^{\prime}$-CAACTGACCCAAACATCATACCC-3'; $M t$-TFA mRNA , $5^{\prime}$-AGCCGCATCGCCGTCTCCTA- $3^{\prime}$ and $5^{\prime}$-CAGCGCTGAGTCGGTCACCC- $3^{\prime}$; ERR $\alpha$ mRNA, $5^{\prime}$-GGGGAGCATCGAGTACAGC-3' and $5^{\prime}$-AGACGCACACCCTCCTTGA-3'; $\beta$-actin mRNA, $5^{\prime}$-TAAGGAGAAGCTGTGCTACG-3' and $5^{\prime}$-ATACTCCTGCTTGCTGATCC- $3^{\prime}$. The quantitative PCR reactions was performed with the following program of denaturation at $95^{\circ} \mathrm{C}$ for $1 \mathrm{~min}$, annealing at $95^{\circ} \mathrm{C}$ for $15 \mathrm{~s}$, and elongation at $60^{\circ} \mathrm{C}$ for $45 \mathrm{~s}$. Results were presented as levels of expression relative to those of controls after normalization to $\beta$-actin using the $2^{-\Delta \Delta C t}$ method [78].

\subsection{Preparation of FITC-Labeled G6}

The FITC-labeled G6 was prepared according to the published literature with slight modifications [79]. Briefly, G6 (100 mg) were dissolved in $2 \mathrm{mM}$ of $10 \%$ hexamethylenediamine acetate solution. Then, $4 \mathrm{mM}$ of $\mathrm{NaBH} 3 \mathrm{CN}$ was added to make the molar ratio of $\mathrm{NaBH}_{3} \mathrm{CN}: 10 \%$ hexamethylenediamine acetate:G6 to be approximately 200:100:1, and then stirred for $12 \mathrm{~h}$ in the dark. The $\mathrm{pH}$ value of the resulting solution was adjusted to 7 with $\mathrm{HCl}$. After that, the reactant was subjected to dialysis (MW $500 \mathrm{Da}$ ) and then freeze-dried. The product was re-dissolved in the $\mathrm{Na}_{2} \mathrm{CO}_{3} / \mathrm{NaHCO}_{3}$ buffer $(\mathrm{pH}=9)$, and then FITC $(10 \mathrm{mg})$ was added. Finally, the mixture was heated for $24 \mathrm{~h}$ at $45^{\circ} \mathrm{C}$ and subjected to dialysis for another $24 \mathrm{~h}$, and then freeze-dried.

\subsection{Intracellular Localization of $G 6$}

To confirm the intracellular localization of G6, HaCaT cells $\left(1 \times 10^{4} / \mathrm{mL}\right)$ were cultured on glass bottom cell culture dishes and incubated with FITC-G6 $(10 \mu \mathrm{M})$ for $12 \mathrm{~h}$. After being washed three times by PBS, the above cells were incubated with MitoTracker Red CMXRos (50 nM) (Invitrogen, Carlsbad, CA, USA) for $40 \mathrm{~min}$ at $37^{\circ} \mathrm{C}$, and cells were observed under a Nikon A1 confocal microscope (Nikon Corporation, Tokyo, Japan). Confocal fluorescent imaging was conducted as follows: FITC-labeled G6, Ex488/Em520; MitoTracker Red CMXRos, Ex578/Em600.

\subsection{Molecule Docking Studies}

Molecular docking was performed usingAMBER10:EHT forcefield and MOE. Briefly, the X-ray crystal structures of the SIRT1 protein (PDB code:5BTR) was downloaded from the protein data bank (http://www.rcsb.org), and was preprocessed by the UCSF ChimeraX software, including the removal of all hetero-atoms and the water molecules. Additionally, compounds G6 were drawn in Chem3D Pro saved as mol2 format, and then minimized using 10,000 steps of steepest minimization in MOE. After that, the docking research used induced fit docking approach, according to the flexibility of the residues' side chains at the binding site. The produced conformation, which had the best score was selected for the analysis.

\subsection{SIRT1 Inhibitor Interferes with SIRT1 Protein Expression}

The HaCaT cells were pre-incubated with different concentrations of nicotinamide at $37^{\circ} \mathrm{C}$ for $12 \mathrm{~h}$. Next, cells were washed with ice-cold PBS and collected by centrifugation. Protein concentrations were measured by a Pierce ${ }^{\mathrm{TM}}$ BCA Protein Assay Kit (Thermo Fisher Scientific, Waltham, MA, USA). Additionally, the content of SIRT1 protein was measured as mentioned in Section 4.9 above. Finally, the supernatant was collected and stored at $-80^{\circ} \mathrm{C}$ until use.

\subsection{Statistics}

All values are expressed as means \pm S.E.M. Statistical significance was determined by using one-way ANOVA with Bonferroni's post hoc tests between the two groups. The criterion for significance was set at $p<0.05$. 
Author Contributions: Q.L. conducted the research and wrote the paper. D.B., L.Q., and M.S. contributed to the resources. X.L., S.Z., and C.Y. helped with the preparation of FITC-G6. G.Y. and J.H. designed and directed the project. All authors have read and agreed to the published version of the manuscript.

Funding: This research was funded by National Natural Science Foundation of China (81973231, 81402982, 81991522), National Science and Technology Major Project of China (2018ZX09735-004), Qingdao National Laboratory for Marine Science and Technology (2016ASKJ08-2), Taishan Scholar Project Special Funds (TS201511011), Shandong Provincial Major Science and Technology Innovation Project (2018SDKJ0404).

Acknowledgments: This work was supported by National Natural Science Foundation of China (81973231, 81402982, 81991522), National Science and Technology Major Project of China (2018ZX09735-004), Qingdao National Laboratory for Marine Science and Technology (2016ASKJ08-2), Taishan Scholar Project Special Funds (TS201511011), Shandong Provincial Major Science and Technology Innovation Project (2018SDKJ0404). We thank LetPub (www.letpub.com) for its linguistic assistance during the preparation of this manuscript.

Conflicts of Interest: The authors declare no conflict of interest.

\section{Abbreviations}

$\begin{array}{ll}\text { G6 } & \text { L-Hexaguluroic acid hexasodium salt } \\ \text { pGC-1 } \alpha & \text { peroxisome proliferator-activated receptor gamma coactivator-1 alpha } \\ \text { SIRT1 } & \text { sirtuin 1 } \\ \text { ROS } & \text { reactive oxygen species } \\ \text { MMP } & \text { mitochondrial membrane potential } \\ \text { FITC } & \text { fluorescin isothiocyanate } \\ \text { ddH2O } & \text { double-distilled water } \\ \text { NADH } & \text { nicotinamide adenine dinucleotide } \\ \text { PVDF } & \text { polyvinylidene fluoride } \\ & \text { J-Aggregate forming lipophilic cation } \\ \text { JC-1 } & 55^{\prime}, 6,6^{\prime} \text {-tetrachloro- } 1,1^{\prime}, 3,3^{\prime} \text {-tetraethylbenzimidazolcarbocyanine iodide } \\ \text { bSA } & \text { bovine serum albumin }\end{array}$

\section{References}

1. Janjetovic, Z.; Nahmias, Z.P.; Hanna, S.; Jarrett, S.G.; Kim, T.K.; Reiter, R.J.; Slominski, A.T. Melatonin and its metabolites ameliorate ultraviolet B-induced damage in human epidermal keratinocytes. J. Pineal Res. 2014, 57, 90-102. [CrossRef] [PubMed]

2. Lee, C.-W.; Chi, M.-C.; Peng, K.-T.; Chiang, Y.-C.; Hsu, L.-F.; Yan, Y.-L.; Li, H.-Y.; Chen, M.-C.; Lee, I.-T.; Lai, C.-H. Water-Soluble Fullerenol C60 (OH) 36 toward Effective Anti-Air Pollution Induced by Urban Particulate Matter in HaCaT Cell. Int. J. Mol. Sci. 2019, 20, 4259. [CrossRef] [PubMed]

3. Matsumura, Y.; Ananthaswamy, H.N. Toxic effects of ultraviolet radiation on the skin. Toxicol. Appl. Pharmacol. 2004, 195, 298-308. [CrossRef] [PubMed]

4. Debacq-Chainiaux, F.; Leduc, C.; Verbeke, A.; Toussaint, O. UV, stress and aging. Derm. Endocrinol. 2012, 4, 236-240. [CrossRef]

5. Berneburg, M.; Plettenberg, H.; Krutmann, J. Photoaging of human skin. Photodermatol. Photoimmunol. Photomed. Rev. Artic. 2000, 16, 239-244. [CrossRef]

6. Puizina-Ivic, N. Skin aging. Acta Dermatovenerol. Alp. Panon. Adriat. 2008, 17, 47.

7. Yang, T.-H.; Lai, Y.-H.; Lin, T.-P.; Liu, W.-S.; Kuan, L.-C.; Liu, C.-C. Chronic exposure to Rhodobacter sphaeroides extract Lycogen ${ }^{\mathrm{TM}}$ prevents UVA-induced malondialdehyde accumulation and procollagen I down-regulation in human dermal fibroblasts. Int. J. Mol. Sci. 2014, 15, 1686-1699. [CrossRef]

8. Xie, H.; Liu, F.; Liu, L.; Dan, J.; Luo, Y.; Yi, Y.; Chen, X.; Li, J. Protective role of AQP3 in UVA-induced NHSFs apoptosis via Bcl2 up-regulation. Arch. Dermatol. Res. 2013, 305, 397-406. [CrossRef]

9. Ichihashi, M.; Ueda, M.; Budiyanto, A.; Bito, T.; Oka, M.; Fukunaga, M.; Tsuru, K.; Horikawa, T. UV-induced skin damage. Toxicology 2003, 189, 21-39. [CrossRef]

10. Fan, J.; Zhuang, Y.; Li, B. Effects of collagen and collagen hydrolysate from jellyfish umbrella on histological and immunity changes of mice photoaging. Nutrients 2013, 5, 223-233. [CrossRef]

11. Ryu, J.; Park, S.-J.; Kim, I.-H.; Choi, Y.H.; Nam, T.-J. Protective effect of porphyra-334 on UVA-induced photoaging in human skin fibroblasts. Int. J. Mol. Med. 2014, 34, 796-803. [CrossRef] 
12. Kwon, O.S.; Jung, S.H.; Yang, B.S. Topical administration of manuka oil prevents UV-B irradiation-induced cutaneous photoaging in mice. Evid. Based Complementary Altern. Med. 2013, 2013, 930857. [CrossRef]

13. Liu, Y.; Fiskum, G.; Schubert, D. Generation of reactive oxygen species by the mitochondrial electron transport chain. J. Neurochem. 2002, 80, 780-787. [CrossRef]

14. Andreyev, A.Y.; Kushnareva, Y.E.; Starkov, A. Mitochondrial metabolism of reactive oxygen species. Biochem. Mosc. 2005, 70, 200-214. [CrossRef]

15. Harman, D. The biologic clock: The mitochondria? J. Am. Geriatr. Soc. 1972, 20, 145-147. [CrossRef]

16. Trounce, I.; Byrne, E.; Marzuki, S. Decline in skeletal muscle mitochondrial respiratory chain function: Possible factor in ageing. Lancet 1989, 333, 637-639. [CrossRef]

17. Yen, T.-C.; Chen, Y.-S.; King, K.-L.; Yeh, S.-H.; Wei, Y.-H. Liver mitochondrial respiratory functions decline with age. Biochem. Biophys. Res. Commun. 1989, 165, 994-1003. [CrossRef]

18. Frenzei, H.; Feimann, J. Age-dependent structural changes in the myocardium of rats. A quantitative light- and electron-microscopic study on the right and left chamber wall. Mech. Ageing Dev. 1984, 27, 29-41. [CrossRef]

19. Cottrell, D.A.; Turnbull, D.M. Mitochondria and ageing. Curr. Opin. Clin. Nutr. Metab. Care 2000, 3, 473-478. [CrossRef]

20. Maes, D.; Collins, D.; Declercq, L.; Foyouzi-Yousseffi, R.; Gan, D.; Mammone, T.; Pelle, E.; Marenus, K.; Gedeon, H. Improving cellular function through modulation of energy metabolism. Int. J. Cosmet. Sci. 2004, 26, 268-269. [CrossRef]

21. Declerq, L. Cosmetic benefits from modulation of cellular energy metabolism. In Energy Skin Delivery Systems: Transdermals, Dermatologicals, and Cosmetic Actives, 1st ed.; Wiley-Blackwell: Ames, NJ, USA, 2006; pp. 117-124.

22. Nacarelli, T.; Azar, A.; Sell, C. Inhibition of mTOR prevents ROS production initiated by ethidium bromide-induced mitochondrial DNA depletion. Front. Endocrinol. 2014, 5, 122. [CrossRef] [PubMed]

23. Xu, Z.; Huo, J.; Ding, X.; Yang, M.; Li, L.; Dai, J.; Hosoe, K.; Kubo, H.; Mori, M.; Higuchi, K. Coenzyme Q10 improves lipid metabolism and ameliorates obesity by regulating CaMKII-mediated PDE4 inhibition. Sci. Rep. 2017, 7, 8253. [CrossRef] [PubMed]

24. Zhang, B.; Chen, J.; Cheng, A.S.; Ko, B.C. Depletion of sirtuin 1 (SIRT1) leads to epigenetic modifications of telomerase (TERT) gene in hepatocellular carcinoma cells. PLoS ONE 2014, 9, e84931. [CrossRef] [PubMed]

25. Huang, J.; Gan, Q.; Han, L.; Li, J.; Zhang, H.; Sun, Y.; Zhang, Z.; Tong, T. SIRT1 overexpression antagonizes cellular senescence with activated ERK/S6k1 signaling in human diploid fibroblasts. PLoS ONE 2008, 3, e1710. [CrossRef] [PubMed]

26. Ming, M.; Zhao, B.; Shea, C.R.; Shah, P.; Qiang, L.; White, S.R.; Sims, D.M.; He, Y.-Y. Loss of sirtuin 1 (SIRT1) disrupts skin barrier integrity and sensitizes mice to epicutaneous allergen challenge. J. Allergy Clin. Immunol. 2015, 135, 936-945. [CrossRef] [PubMed]

27. Michan, S.; Sinclair, D. Sirtuins in mammals: Insights into their biological function. Biochem. J. 2007, 404, 1-13. [CrossRef] [PubMed]

28. Salminen, A.; Kaarniranta, K.; Kauppinen, A. Crosstalk between oxidative stress and SIRT1: Impact on the aging process. Int. J. Mol. Sci. 2013, 14, 3834-3859. [CrossRef]

29. Khan, R.S.; Dine, K.; Sarma, J.D.; Shindler, K.S. SIRT1 activating compounds reduce oxidative stress mediated neuronal loss in viral induced CNS demyelinating disease. Acta Neuropathol. Commun. 2014, 2, 3. [CrossRef]

30. Zarzuelo, M.J.; López-Sepúlveda, R.; Sánchez, M.; Romero, M.; Gómez-Guzmán, M.; Ungvary, Z.; Pérez-Vizcaíno, F.; Jiménez, R.; Duarte, J. SIRT1 inhibits NADPH oxidase activation and protects endothelial function in the rat aorta: Implications for vascular aging. Biochem. Pharmacol. 2013, 85, 1288-1296. [CrossRef]

31. Lopez-Lluch, G.; Hunt, N.; Jones, B.; Zhu, M.; Jamieson, H.; Hilmer, S.; Cascajo, M.; Allard, J.; Ingram, D.; Navas, P.; et al. Calorie restriction induces mitochondrial biogenesis and bioenergetic efficiency. Proc. Natl. Acad. Sci. USA 2006, 103, 1768-1773. [CrossRef]

32. Xu, J.-Y.; Wu, L.-Y.; Zheng, X.-Q.; Lu, J.-L.; Wu, M.-Y.; Liang, Y.-R. Green Tea Polyphenols Attenuating Ultraviolet B-Induced Damage to Human Retinal Pigment Epithelial Cells in Vitro. Investig. Ophthalmol. Vis. Sci. 2010, 51, 6665-6670. [CrossRef] [PubMed]

33. Thompson, B.C.; Surjana, D.; Halliday, G.M.; Damian, D.L. Nicotinamide enhances repair of ultraviolet radiation-induced DNA damage in primary melanocytes. Exp. Dermatol. 2014, 23, 509-511. [CrossRef] [PubMed]

34. Park, J.; Halliday, G.M.; Surjana, D.; Damian, D.L. Nicotinamide prevents ultraviolet radiation-induced cellular energy loss. Photochem. Photobiol. 2010, 86, 942-948. [CrossRef] [PubMed] 
35. Jacobson, E.L.; Shieh, W.M.; Huang, A.C. Mapping the role of NAD metabolism in prevention and treatment of carcinogenesis. In ADP-Ribosylation Reactions: From Bacterial Pathogenesis to Cancer; Springer: Berlin/Heidelberg, Germany, 1999; pp. 69-74.

36. Fang, E.F.; Scheibye-Knudsen, M.; Brace, L.E.; Kassahun, H.; SenGupta, T.; Nilsen, H.; Mitchell, J.R.; Croteau, D.L.; Bohr, V.A. Defective mitophagy in XPA via PARP-1 hyperactivation and NAD ${ }^{+} / \mathrm{SIRT} 1$ reduction. Cell 2014, 157, 882-896. [CrossRef]

37. Teixeira, J.; Deus, C.M.; Borges, F.; Oliveira, P.J. Mitochondria: Targeting mitochondrial reactive oxygen species with mitochondriotropic polyphenolic-based antioxidants. Int. J. Biochem. Cell Biol. 2018, 97, 98-103. [CrossRef]

38. Pinnell, S.R. Cutaneous photodamage, oxidative stress, and topical antioxidant protection. J. Am. Acad. Dermatol. 2003, 48, 1-22. [CrossRef]

39. Bachelor, M.A.; Bowden, G.T. UVA-mediated activation of signaling pathways involved in skin tumor promotion and progression. Semin. Cancer Biol. 2004, 14, 131-138. [CrossRef]

40. Fuchs, J.; Packer, L. Photooxidative stress in the skin. Oxidative Stress Oxid. Antioxid. 1991, 26, 559-583.

41. Heck, D.E.; Gerecke, D.R.; Vetrano, A.M.; Laskin, J.D. Solar ultraviolet radiation as a trigger of cell signal transduction. Toxicol. Appl. Pharmacol. 2004, 195, 288-297. [CrossRef]

42. Xu, P.; Zhang, M.; Wang, X.; Yan, Y.; Chen, Y.; Wu, W.; Zhang, L.; Zhang, L. Antioxidative effect of quetiapine on acute ultraviolet-B-induced skin and HaCaT cell damage. Int. J. Mol. Sci. 2018, 19, 953. [CrossRef]

43. Syed, D.N.; Malik, A.; Hadi, N.; Sarfaraz, S.; Afaq, F.; Mukhtar, H. Photochemopreventive effect of pomegranate fruit extract on UVA-mediated activation of cellular pathways in normal human epidermal keratinocytes. Photochem. Photobiol. 2006, 82, 398-405. [CrossRef] [PubMed]

44. Davinelli, S.; Bertoglio, J.C.; Polimeni, A.; Scapagnini, G. Cytoprotective polyphenols against chronological skin aging and cutaneous photodamage. Curr. Pharm. Des. 2018, 24, 99-105. [CrossRef] [PubMed]

45. Mirshafiey, A.; Hosseini, S.; Afraei, S.; Rastkari, N.T.; Zavareh, F.; Azizi, G. Anti-aging property of G2013 molecule as a novel immunosuppressive agent on enzymatic and non-enzymatic oxidative stress determinants in rat model. Curr. Drug Discov. Technol. 2016, 13, 25-33. [CrossRef] [PubMed]

46. Hosseini, F.; Mahdian-Shakib, A.; Jadidi-Niaragh, F.; Enderami, S.E.; Mohammadi, H.; Hemmatzadeh, M.; Mohammed, H.A.; Anissian, A.; Kokhaei, P.; Mirshafiey, A. Anti-inflammatory and anti-tumor effects of $\alpha$-l-guluronic acid (G2013) on cancer-related inflammation in a murine breast cancer model. Biomed. Pharmacother. 2018, 98, 793-800. [CrossRef]

47. Schniertshauer, D.; Gebhard, D.; Bergemann, J. Age-dependent loss of mitochondrial function in epithelial tissue can be reversed by coenzyme Q10. J. Aging Res. 2018, 2018, 2090-2212. [CrossRef]

48. Krutmann, J.; Schroeder, P. Role of mitochondria in photoaging of human skin: The defective powerhouse model. J. Investig. Dermatol. Symp. Proc. 2009, 14, 44-49. [CrossRef]

49. Brunk, U.T.; Terman, A. The mitochondrial-lysosomal axis theory of aging: Accumulation of damaged mitochondria as a result of imperfect autophagocytosis. Eur. J. Biochem. 2002, 269, 1996-2002. [CrossRef]

50. Clayton, D.A.; Doda, J.N.; Friedberg, E.C. The absence of a pyrimidine dimer repair mechanism in mammalian mitochondria. Proc. Natl. Acad. Sci. USA 1974, 71, 2777-2781. [CrossRef]

51. Demple, B.; Harrison, L. Repair of oxidative damage to DNA: Enzymology and biology. Annu. Rev. Biochem. 1994, 63, 915-948. [CrossRef]

52. Wallace, D.C. A mitochondrial paradigm of metabolic and degenerative diseases, aging, and cancer: A dawn for evolutionary medicine. Annu. Rev. Genet. 2005, 39, 359-407. [CrossRef]

53. Finley, L.W.; Haigis, M.C. The coordination of nuclear and mitochondrial communication during aging and calorie restriction. Ageing Res. Rev. 2009, 8, 173-188. [CrossRef] [PubMed]

54. Butow, R.A.; Avadhani, N.G. Mitochondrial signaling: The retrograde response. Mol. Cell 2004, 14, 1-15. [CrossRef]

55. Chae, S.; Ahn, B.Y.; Byun, K.; Cho, Y.M.; Yu, M.-H.; Lee, B.; Hwang, D.; Park, K.S. A systems approach for decoding mitochondrial retrograde signaling pathways. Sci. Signal. 2013, 6, rs4. [CrossRef]

56. Jazwinski, S.M.; Kriete, A. The yeast retrograde response as a model of intracellular signaling of mitochondrial dysfunction. Front. Physiol. 2012, 3, 139. [CrossRef] [PubMed]

57. Kumar, R.; Nigam, L.; Singh, A.P.; Singh, K.; Subbarao, N.; Dey, S. Design, synthesis of allosteric peptide activator for human SIRT1 and its biological evaluation in cellular model of Alzheimer's disease. Eur. J. Med. Chem. 2017, 127, 909-916. [CrossRef] [PubMed] 
58. Beher, D.; Wu, J.; Cumine, S.; Kim, K.W.; Lu, S.C.; Atangan, L.; Wang, M. Resveratrol is not a direct activator of SIRT1 enzyme activity. Chem. Biol. Drug Des. 2009, 74, 619-624. [CrossRef] [PubMed]

59. Higashida, K.; Kim, S.H.; Jung, S.R.; Asaka, M.; Holloszy, J.O.; Han, D.-H. Effects of resveratrol and SIRT1 on PGC-1 $\alpha$ activity and mitochondrial biogenesis: A reevaluation. PLoS Biol. 2013, 11, e1001603. [CrossRef] [PubMed]

60. Guarente, L. Calorie restriction and sirtuins revisited. Genes Dev. 2013, 27, 2072-2085. [CrossRef]

61. Satoh, A.; Imai, S.-I. Hypothalamic Sirt1 in aging. Aging Albany NY 2014, 6, 1. [CrossRef]

62. Sweeney, G.; Song, J. The association between PGC-1 $\alpha$ and Alzheimer's disease. Anat. Cell Biol. 2016, 49, 1-6. [CrossRef]

63. Schaefer, M.; Werner, S. Nrf2-A regulator of keratinocyte redox signaling. Free Radic. Biol. Med. 2015, 88, 243-252. [CrossRef] [PubMed]

64. Janjetovic, Z.; Jarrett, S.G.; Lee, E.F.; Duprey, C.; Reiter, R.J.; Slominski, A.T. Melatonin and its metabolites protect human melanocytes against UVB-induced damage: Involvement of NRF2-mediated pathways. Sci. Rep. 2017, 7, 1274. [CrossRef] [PubMed]

65. Langie, S.A.; Kowalczyk, P.; Tudek, B.; Zabielski, R.; Dziaman, T.; Oliński, R.; van Schooten, F.J; Godschalk, R.W. The effect of oxidative stress on nucleotide-excision repair in colon tissue of newborn piglets. Mutat. Res. Genet. Toxicol. Environ. Mutagenesis 2010, 695, 75-80. [CrossRef]

66. Han, W.; Ming, M.; Zhao, R.; Pi, J.; Wu, C.; He, Y.-Y. Nrf1 CNC-bZIP protein promotes cell survival and nucleotide excision repair through maintaining glutathione homeostasis. J. Biol. Chem. 2012, 287, 18788-18795. [CrossRef] [PubMed]

67. Rodgers, J.T.; Lerin, C.; Haas, W.; Gygi, S.P.; Spiegelman, B.M.; Puigserver, P. Nutrient control of glucose homeostasis through a complex of PGC-1 $\alpha$ and SIRT1. Nature 2005, 434, 113. [CrossRef]

68. Lehman, J.J.; Barger, P.M.; Kovacs, A.; Saffitz, J.E.; Medeiros, D.M.; Kelly, D.P. Peroxisome proliferator-activated receptor $\gamma$ coactivator-1 promotes cardiac mitochondrial biogenesis. J. Clin. Investig. 2000, 106, 847-856. [CrossRef]

69. Wu, Z.; Puigserver, P.; Andersson, U.; Zhang, C.; Adelmant, G.; Mootha, V.; Troy, A.; Cinti, S.; Lowell, B.; Scarpulla, R.C. Mechanisms controlling mitochondrial biogenesis and respiration through the thermogenic coactivator PGC-1. Cell 1999, 98, 115-124. [CrossRef]

70. Chiang, H.-M.; Chen, C.-W.; Lin, T.-Y.; Kuo, Y.-H. N-phenethyl caffeamide and photodamage: Protecting skin by inhibiting type I procollagen degradation and stimulating collagen synthesis. Food Chem. Toxicol. 2014, 72, 154-161. [CrossRef]

71. Wu, P.-Y.; Huang, C.-C.; Chu, Y.; Huang, Y.-H.; Lin, P.; Liu, Y.-H.; Wen, K.-C.; Lin, C.-Y.; Hsu, M.-C.; Chiang, H.-M. Alleviation of ultraviolet B-induced photodamage by Coffea arabica extract in human skin fibroblasts and hairless mouse skin. Int. J. Mol. Sci. 2017, 18, 782. [CrossRef]

72. Tirosh, O.; Sen, C.; Roy, S.; Packer, L. Cellular and mitochondrial changes in glutamate-induced HT4 neuronal cell death. Neuroscience 2000, 97, 531-541. [CrossRef]

73. Wölfle, U.; Esser, P.R.; Simon-Haarhaus, B.; Martin, S.F.; Lademann, J.; Schempp, C.M. UVB-induced DNA damage, generation of reactive oxygen species, and inflammation are effectively attenuated by the flavonoid luteolin in vitro and in vivo. Free Radic. Biol. Med. 2011, 50, 1081-1093. [CrossRef] [PubMed]

74. Chiang, H.-M.; Chan, S.-Y.; Chu, Y.; Wen, K.-C. Fisetin ameliorated photodamage by suppressing the mitogen-activated protein kinase/matrix metalloproteinase pathway and nuclear factor-кB pathways. J. Agric. Food Chem. 2015, 63, 4551-4560. [CrossRef] [PubMed]

75. Patanè, G.; Anello, M.; Piro, S.; Vigneri, R.; Purrello, F.; Rabuazzo, A.M. Role of ATP production and uncoupling protein-2 in the insulin secretory defect induced by chronic exposure to high glucose or free fatty acids and effects of peroxisome proliferator-activated receptor- $\gamma$ inhibition. Diabetes 2002, 51, 2749-2756. [CrossRef]

76. Kumar, M.J.; Nicholls, D.G.; Andersen,J.K. METABOLISM AND BIOENERGETICS-Oxidative a-Ketoglutarate Dehydrogenase Inhibition via Subtle Elevations in Monoamine Oxidase B Levels Results in Loss of Spare Respiratory Capacity. IMPLICATIONS FOR. J. Biol. Chem. 2003, 278, 46432-46439. [CrossRef] [PubMed]

77. Humphries, K.M.; Szweda, L.I. Selective inactivation of $\alpha$-ketoglutarate dehydrogenase and pyruvate dehydrogenase: Reaction of lipoic acid with 4-hydroxy-2-nonenal. Biochemistry 1998, 37, 15835-15841. [CrossRef] [PubMed] 
78. Livak, K.J.; Schmittgen, T.D. Analysis of relative gene expression data using real-time quantitative PCR and the $2^{-\Delta \Delta C T}$ method. Methods 2001, 25, 402-408. [CrossRef] [PubMed]

79. De Belder, A.; Granath, K. Preparation and properties of fluorescein-labelled dextrans. Carbohydr. Res. 1973, 30, 375-378. [CrossRef] 